ENVIRONMENTAL

RESTORATION

PROGRAM

$$
\begin{gathered}
J A H-5164 \\
\text { OSTI }
\end{gathered}
$$

Surveillance Plan for Environmental Monitoring in Waste Area Grouping 6 at Oak Ridge National Laboratory, Oak Ridge, Tennessee 


Gilbert/Commonwealth, Inc.
contributed to the preparation of this document and
should not be considered an eligible contractor for its
review.

This report has been reproduced directly from the best avallable copy.

Available to DOE and DOE contractors from the Office of Scientific and Technical Information, P.O. Box 62 , Oak Rldge, TN 37831; prices avallable from 615-576-8401.

Available to the public from the National Technical Information Service, U.S. Department of Commerce, 5285 Port Royal Rd., Springfield, VA 22161.

\section{DISCAAIMRR}

This report was prepared as an account of work sponsored by an agency of the United States Government. Neither the United States Government nor any agency thereof, nor any of their employees, makes any warranty, express or implied, or assumes any legal liability or responsibility for the accuracy, completeness, or usefulness of any information, apparatus, product, or process disclosed, or represents that its use would not infringe privately owned rights. Reference herein to any specific commercial product, process, or service by trade name, trademark, manufacturer, or otherwise, does not necessarily constitute or imply its endorsement, recommendation, or favoring by the United States Government or any agency thereof. The views and opinions of authors expressed herein do not necessarily state or reflect those of the United States Government or any agency thereof. 
ORNL/ER-209

Energy Systems Environmental Restoration Program ORNL Environmental Restoration Program

\title{
Surveillance Plan for Environmental Monitoring in Waste Area Grouping 6 at Oak Ridge National Laboratory, Oak Ridge, Tennessee
}

Date Issued-December 1993

\author{
Prepared by \\ Gilbert/Commonwealth, Inc. \\ Knoxville, Tennessee \\ under subcontract 32K-UB147C
}

Prepared for

U.S. Department of Energy

Office of Environmental Restoration and Waste Management under budget and reporting code EW 20

OAK RIDGE NATIONAL LABORATORY

Oak Ridge, Tennessee 37831-6285

managed by

MARTIN MARIETTA ENERGY SYSTEMS, INC.

for the

U.S. DEPARTMENT OF ENERGY

under contract DE-AC05-84OR21400

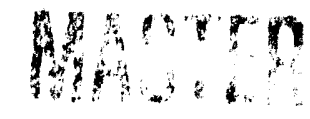


Surveillance Plan for Environmental Monitoring in Waste Area Grouping 6 at Oak Ridge National Laboratory, Oak Ridge, Tennessee

Approvals

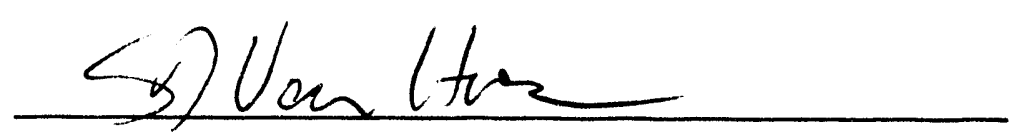

S. D. Van Hoesen WAG 6 Project Manager

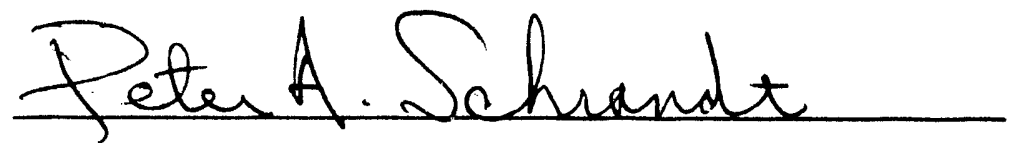

P. A. Schrandt Environmental Restoration Quality Assurance Specialist
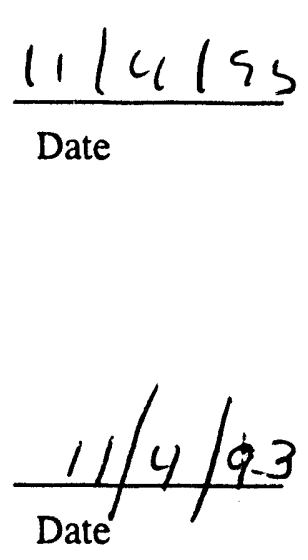


\section{CONTENTS}

ABBREVIATIONS $\ldots \ldots \ldots \ldots \ldots \ldots \ldots \ldots \ldots \ldots \ldots \ldots \ldots \ldots$ iv EXECUTTVE SUMMARY $\ldots \ldots \ldots \ldots \ldots \ldots \ldots \ldots \ldots \ldots \ldots$

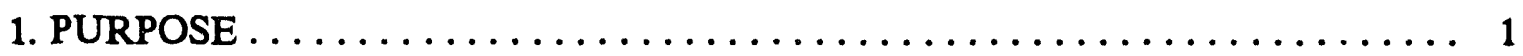

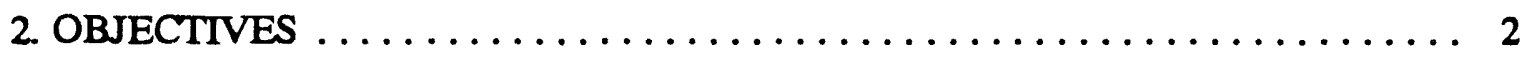

3. RESPONSIBILITIES $\ldots \ldots \ldots \ldots \ldots \ldots \ldots \ldots \ldots \ldots \ldots \ldots \ldots \ldots$

4. ROUTINE ACTIONS ........................ 4

5. SCHEDULED SURVEILLANCE $\ldots \ldots \ldots \ldots \ldots \ldots \ldots \ldots \ldots \ldots \ldots \ldots$

6. REQUIREMENTS $\ldots \ldots \ldots \ldots \ldots \ldots \ldots \ldots \ldots \ldots \ldots \ldots \ldots \ldots \ldots \ldots$

7. DOCUMENTATION $\ldots \ldots \ldots \ldots \ldots \ldots \ldots \ldots \ldots \ldots \ldots \ldots \ldots \ldots$ 


\section{ABBREVIATIONS}

$\begin{array}{ll}\text { APO } & \text { Analytical Projects Office } \\ \text { C\&TS } & \text { Computing and Telecommunications Services } \\ \text { CDM } & \text { CDM Federal Programs } \\ \text { ER } & \text { Environmental Restoration } \\ \text { ESD } & \text { Environmental Sciences Division } \\ \text { ESP } & \text { Environmental Surveillance and Protection } \\ \text { MAD } & \text { Section } \\ \text { QAS } & \text { Measurement and Applications Division } \\ \text { SAIC } & \text { Quality Assurance Specialist } \\ \text { WAG } & \text { ScienceApplications InternationalCorporation } \\ \text { WM\&RA } & \text { Waste Area Grouping } \\ & \text { Waste Management and Remedial Action } \\ \end{array}$




\section{EXECUTIVE SUMMARY}

This Surveillance Plan has been developed as part of the Environmental Monitoring Plan for Waste Area Grouping 6 at Oak Ridge National Laboratory, Oak Ridge, Tennessee (DOE/OR/01-1192\&D1). Environmental monitoring will be conducted in two phases: the baseline monitoring phase and the routine annual monitoring phase. The baseline monitoring phase will be conducted to establish the baseline contaminant release conditions at the Waste Area Grouping (WAG), to confirm the site-related chemicals of concern (COC), and to gather data to confirm the site hydrologic model. The baseline monitoring phase is expected to begin in 1994 and continue for 12-18 months. The routine annual monitoring phase will consist of continued sampling and analyses of COC to determine off-WAG contaminant flux, to identify trends in releases, and to confirm the COC. The routine annual monitoring phase will continue for $\sim 4$ years after completion of the baseline monitoring phase.

This Surveillance Plan presents the technical and quality assurance surveillance activities for the various WAG 6 environmental monitoring and data evaluation plans and implementing procedures. 


\section{PURPOSE}

This plan delineates the surveillance activities required to verify compliance with the technical and quality aspects of the various Waste Area Grouping (WAG) 6 plans and implementing procedures. The plans include the WAG 6 Environmental Monitoring Plan, Sampling and Analysis Plans, Waste Management Plan, Health and Safety Plan, Data Management Plan and Functional System Design, and the Quality Assurance Project Plan. The surveillance activities help support the WAG 6 self-assessment programs, and they help generate feedback on the acceptability and effectiveness of established management controls governing WAG 6 environmental monitoring activities. 


\section{OBJECTIVES}

Specific surveillance activities are identified and scheduled to verify conformance to requirements as established in WAG 6 plans and procedures.

Environmental Restoration (ER) Division Procedure ER/C-P1600 or the existing procedures of the organization performing surveillances govern the surveillance activities and resolution of findings or negative observations. If another organization's procedure is used, the WAG 6 Program Manager or ER Quality Assurance Specialist (QAS) must approve the procedure and validate that it meets the intent of ER Division procedures.

ER program management and all organizations performing work in the WAG 6 Environmental Monitoring Program are responsible for surveillances. Procedures and policies of the participating organization will specify how surveillance activities are performed. Findings and negative observations are to be discussed with the personnel from the affected organization at the time of discovery to ensure that the observations are valid and to facilitate immediate corrective action. Additionally, the surveillance results are to be documented in a letter report and issued within 30 days of the surveillance. The WAG 6 Program Manager, ER QAS, and ER Document Management Center should receive copies of the report. 


\section{RESPONSIBILITIES}

This plan describes the surveillance activities and responsibilities charged to the WAG 6 Environmental Monitoring Program Team as well as those charged to Oak Ridge National Laboratory (ORNL) support organizations.

The key organizations are as follows:

- ORNL ER Program,

- Central Engineering Services,

- Environmental Sciences Division (ESD),

- Computing and Telecommunications Services (C\&TS),

- Analytical Projects Office (APO),

- Environmental Surveillance and Protection Section (ESP),

- Waste Management and Remedial Action Division (WM\&RA),

- Measurement Applications and Development Group (MAD),

- CDM Federal Programs (CDM), and

- Science Applications International Corporation (SAIC). 


\section{ROUTINE ACTIONS}

Routine surveillance activities include field inspections, guidance, direction, and coordination during the daily operations. They often result in decisions that improve the overall operation of the project. Activities such as these, including the impact, should be documented as part of the self-assessment program. Certain routine surveillance activities, such as radiological monitoring during entrance and exit of the WAG, safety inspection of equipment and personnel and security scans, etc., are addressed in the Surveillance and Maintenance Plan for Waste Area Groupings at Oak Ridge National Laboratory for FY 19932002, (ORNL-ER-39). 


\section{SCHEDULED SURVEILLANCE}

The following schedule compiles the planned surveillance activities for the WAG 6 Environmental Monitoring Program.

Table 1. Schedule

\begin{tabular}{|c|c|c|}
\hline Activity & Organization & Frequency \\
\hline Surface water and sediment sampling & CDM & $\begin{array}{l}\text { Initially and at } 4-6 \text { week } \\
\text { intervals }\end{array}$ \\
\hline $\begin{array}{l}\text { Surface water monitoring equipment } \\
\text { maintenance }\end{array}$ & CDM & $\begin{array}{l}\text { Initially and at } 4-6 \text { week } \\
\text { intervals }\end{array}$ \\
\hline Waste handling practices & CDM & $\begin{array}{l}\text { Initially and at } 4-6 \text { week } \\
\text { intervals }\end{array}$ \\
\hline Chain of custody & $\mathrm{CDM}$ & $\begin{array}{l}\text { Initially and at } 4-6 \text { week } \\
\text { intervals }\end{array}$ \\
\hline Field documentation & CDM & $\begin{array}{l}\text { Initially and at } 4-6 \text { week } \\
\text { intervals }\end{array}$ \\
\hline Field training records & CDM & $\begin{array}{l}\text { Initially and at } 4-6 \text { week } \\
\text { intervals }\end{array}$ \\
\hline Field quality control procedures & CDM & $\begin{array}{l}\text { Initially and at } 4-6 \text { week } \\
\text { intervals }\end{array}$ \\
\hline Laboratory procedures & CDM & Initially and quarterly \\
\hline Laboratory analysis & CDM & Initially and quarterly \\
\hline Laboratory quality control & CDM & Initially and quarterly \\
\hline Office operations/documentation & CDM & $\begin{array}{l}\text { Initially and at } 4-6 \text { week } \\
\text { intervals }\end{array}$ \\
\hline Data validation (office surveillance) & CDM & $\begin{array}{l}\text { Initially and at } 4-6 \text { week } \\
\text { intervals }\end{array}$ \\
\hline Data management (office surveillance) & CDM & $\begin{array}{l}\text { Initially and at } 4-6 \text { week } \\
\text { intervals }\end{array}$ \\
\hline Records (office surveillance) & CDM & $\begin{array}{l}\text { Initially and at } 4-6 \text { week } \\
\text { intervals }\end{array}$ \\
\hline $\begin{array}{l}\text { Groundwater quality monitoring } \\
\text { activities (internal) }\end{array}$ & ESP & Quarterly \\
\hline Groundwater level monitoring activities & CDM & $\begin{array}{l}\text { Initially and at } 4-6 \text { week } \\
\text { intervals }\end{array}$ \\
\hline Measurement assurance audits of ESP & MAD & Annually \\
\hline
\end{tabular}


Table 1 (continued)

\begin{tabular}{lcl}
\hline Activity & Organization & \multicolumn{1}{c}{ Frequency } \\
\hline $\begin{array}{l}\text { Data management assessment } \\
\text { procedures }\end{array}$ & SAIC & Quarterly \\
$\begin{array}{l}\text { Groundwater modeling software } \\
\text { Surface water modeling software }\end{array}$ & ESD & Initially and periodically \\
$\begin{array}{l}\text { Surface water sampling activities } \\
\text { Data validation, evaluation and entries }\end{array}$ & ESD & $\begin{array}{l}\text { Initially and periodically } \\
\text { Initially and periodically }\end{array}$ \\
$\begin{array}{l}\text { Data management plan and functional } \\
\text { systems design requirements } \\
\text { Waste management activities }\end{array}$ & C\&TS & $\begin{array}{l}\text { Initially and at 4-6 week } \\
\text { intervals } \\
\text { Initi llly and quarterly }\end{array}$ \\
Health and safety & WM\&RA & $\begin{array}{l}\text { Initially and } \\
\text { semiannually }\end{array}$ \\
Laboratory audits & MAD & $\begin{array}{l}\text { Initially and at 4-6 week } \\
\text { intervals } \\
\text { Semiannually; project- } \\
\text { specific as required; } \\
\text { quarterly performance } \\
\text { evaluation }\end{array}$ \\
& APO & Weekly \\
\hline
\end{tabular}

The above schedule may be supplemented by additional surveillances for one or more of the following reasons:

- significant changes in the environmental monitoring plan occur,

- new or changed standards or regulations are imposed,

- changes in personnel or the organization occur,

- significant changes in quality occur,

- additional verification of previously identified corrective actions is needed, or

- the WAG 6 Program Manager requests additional surveillances. 


\section{REQUIREMENTS}

All surveillance activities will be performed in accordance with procedures as stated in Sect. 2 of this plan. Surveillance activities will be conducted using a checklist developed from the procedure(s) or work plan being followed to perform the actual work. Each item on the surveillance checklist will identify the document and the location within the document that establishes the requirement being reviewed. The checklist will identify whether the item was found to be satisfactory or unsatisfactory, and, in case of an unsatisfactory observation, sufficient narrative will be provided in a "comments" column to support the conclusion. If a satisfactory observation is noted, any good practices or other significant information should be included in a "comments" column. If the checklist does not include a narrative, then the surveillance report must provide the needed information. All items identified as unsatisfactory will be entered into a corrective action tracking system and resolved in a timely manner, in accordance with ER/C-P1600. 


\section{DOCUMENTATION}

All surveillance reports/checklists will be maintained as quality assurance records, and copies will be sent to the WAG 6 Program Manager, to the ER QAS, and to the ER Document Management Center. In addition, a copy of all environmental, safety and health, and waste management surveillance reports/checklisis will be sent to the ER Health and Safety/Waste Management Manager. 


\section{CONTROLLED DISTRIBUTION}

1. T. S. Ball

2. S. N. Burman

3. S. E. Childs

4. R. B. Clapp

5. H. D. Clark

6. W. C. Hayes

7. R. B. Knott

8. S. L Laman

9. J. R. Mathis

10. G. R. Moline

11. P. A. Schrandt

12. S. D. Van Hoesen

13. D. R. Watkins

14. K. A. Wilson

15. R. C. Williams

16-18. ORNL ER Document Management Center-RC

19. C. L. Callis, CDM Federal Programs Corporation, 800 Oak Ridge Turnpike, Suite 500, Oak Ridge, TN 37830

20. S. Pack, SAIC, 800 Oak Ridge Turnpike, P.O. Box 5202, Oak Ridge, TN 37830

\section{UNCONTROLLED DISTRIBUTION}

21. H. L. Boston

22-24. D. M. Matteo

25-26. P. T. Owen

27. M. M. Stevens

28. P. S. Wood

29. Laboratory Records Department

30. Central Research Library

31-33. Central ER Document Management Center

34. Office of Assistant Manager for Energy Research and Development, DOE Oak Ridge Operations Office, P.O. Box 2001, Oak Ridge, TN 37831-8600

35. C. L. Oaks, Gilbert/Commonwealth, Inc., Suite 200, 1055 Commerce Park Drive, Oak Ridge, TN 37830

36. R. C. Sieeman, DOE Oak Ridge Operations Office, P.O. Box 2001, Oak Ridge, TN 378318541

37. J. T. Sweeney, DOE Oak Ridge Operations Office, P.O. Box 2001, Oak Ridge, TN 37831 8541

38-39. Office of Scientific and Technical Information, P.O. Box 62, Oak Ridge, TN 37831 
$Y$
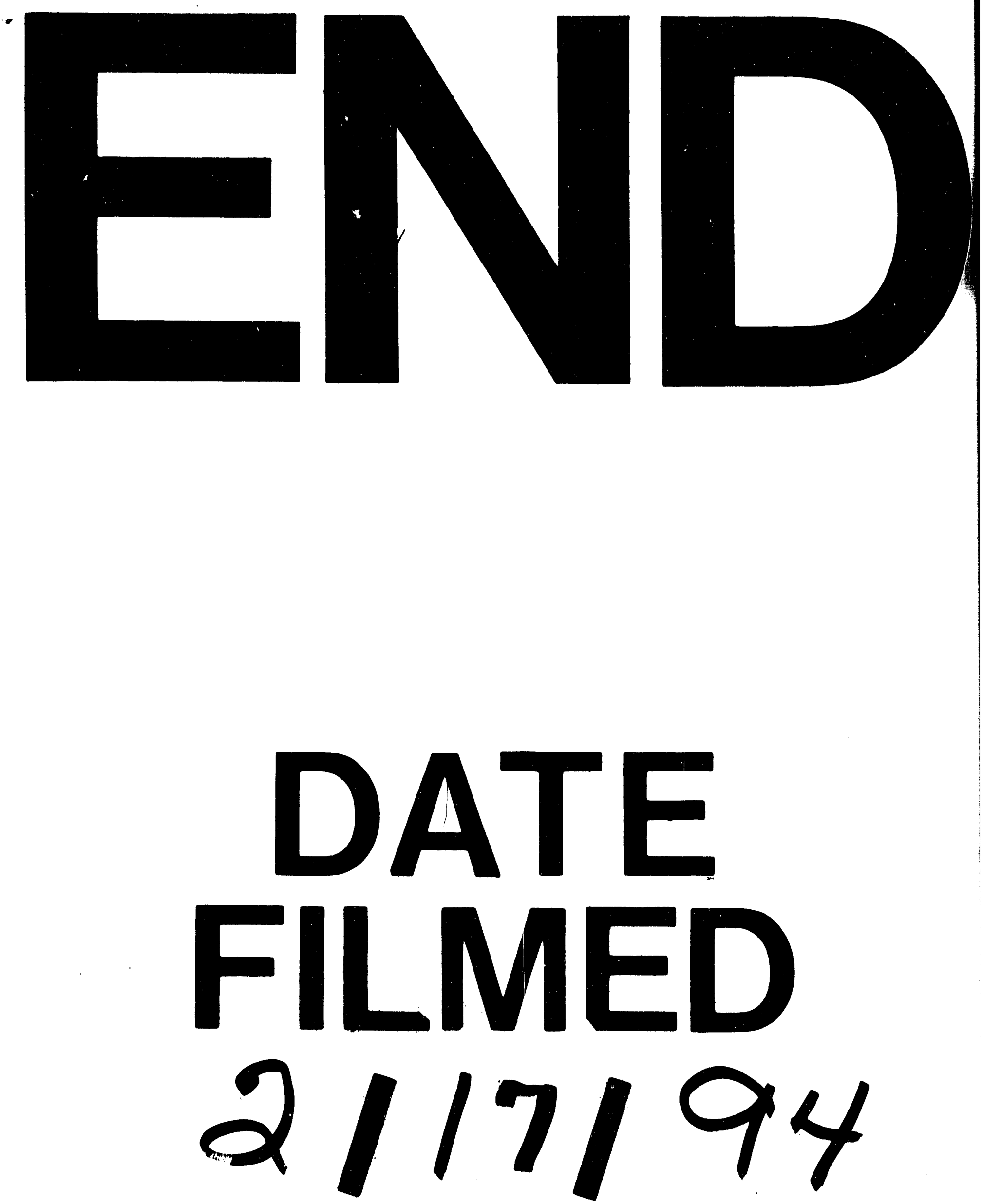

1 
